Vol. 8(40), pp. 3540-3550, 1 October, 2014

DOI: $10.5897 /$ AJ MR2014.6847

Artic le Number. 394454148052

ISSN 1996-0808

Copyright (c) 2014

African Journal of Microbiology Research

Author(s) retain the copyright of this article

http://www.academic joumals.org/AJ MR

\title{
Histological and histochemical changes induced by the amendment of chitosan and inoculation of Pseudomonas sp. against Tomato leaf curl virus (ToLCV) in tomato (Lycopersicon esculentum Mill.)
}

\author{
Shefali Mishra ${ }^{1 *}$, K. S. Jagadeesh ${ }^{1}$, P. U. Krishnaraj ${ }^{2}$ and M. Valan Arasu $^{3}$ \\ ${ }^{1}$ Department of Agricultural Microbiology, University of Agricultural Sciences, Dharwad 580 005, Karnataka, India. \\ ${ }^{2}$ Department of Biotechnology, University of Agricultural Sciences, Dharwad 580 005, Karnataka, India. \\ ${ }^{3}$ Department of Botany and Microbiology, College of Science, King Saud University, Riyadh-11451, Saudi Arabia.
}

Received 22 April, 2014; Accepted 8 September, 2014

\begin{abstract}
This study was conducted to evaluate the comparison between the histological and histochemical changes in leaves of tomato due to tomato leaf curl virus (ToLCV) with or without plant growthpromoting rhizobacteria (PGPR) and chitosan treatments. The combined treatment of chitosan and Pseudomonas sp. induced a significant $(P=0.05)$ increase in the activities of polyphenoloxidase (PPO), peroxidase (POD), chitinase, phenylammonialyase (PAL) and enhanced the content of phenolic compounds in tomato leaves. Furthermore, the combined application reduced the disease severity (\%) of ToLCV in tomato plants. Although, the histopathological and histochemical studies revealed more destruction in the diseased plants, these changes could be reduced to the level of the healthy plants due to combined treatment of chitosan and Pseudomonas sp.
\end{abstract}

Key words: Pseudomonas sp., Tomato leaf curl virus (ToLCV), induced systemic resistance, chitosan, biocontrol, Bemisia tabaci, histopathology.

\section{INTRODUCTION}

Tomato (Solanum lycopersicon L.) is one of the important and most widely grown vegetable crops of both tropics and sub tropics in the world and ranks second in importance among vegetables. Recently, there has been more emphasis on tomato production not only as a source of vitamins, but also as a source of income and food security in many countries including India. There are many production constraints and it is affected by several diseases leading to substantial losses in yield. Of all the viral diseases reported on tomato, tomato leaf curl virus Tomato leaf curl virus (ToLCV), a Geminivirus (family Geminiviridae, genus Begomovirus) is the most important and destructive viral pathogen in many parts of India (Saikia and Muniyappa,1989; Harrison et al., 1991).The disease is transmitted by whitefly (Bemisia tabaci) (Muniyappa and Veeresh, 1984).

The investigation of plant response to elicitors is one of the most rapidly developing lines of inquiry in plant

*Corresponding author. E-mail: shefalibabli9@gmail.com.

Author(s) agree that this article remain permanently open access under the terms of the Creative Commons Attribution License 4.OInternational License 
physiology.

The elicitors stimulate the contact between plants and phytopathogens and, thereby, trigger defensive mechanisms that constrain the invasion of pathogenic fungi, bacteria and viruses.Chitosan is one of the most studied elicitors, and it regulates the expression of resistance genes and induces jasmonate synthesis (Doares et al., 1995). These molecules have been shown to display toxicity and inhibit fungal growth and development. They were reported to be active against viruses, bacteria, and pests as well (Abdelbasset et al., 2010). Based on these proprieties that help strengthen host plant defenses, interest has been growing in using them in agricultural systems to reduce the negative impact of diseases on yield and quality of crops.

Histopathological and biochemical changes occur in tomato leaves after infection by ToLCV resulting in external manifestation in the form of different symptoms. The plants inoculated with Tobacco mosaic virus (TMV) in tomato exhibited the disintegration of palisade tissue with wider space in spongy parenchyma (Alok et al., 1986). There was reduction in the amount of reducing sugars, non-reducing sugars, total sugars, starch and total chlorophyll in the plants infected with yellow mosaic virus as compared to healthy plants (Thind et al., 1996). In case of papaya leaves infected with the Papaya ring spot virus (PRSV), the palisade layers and spongy cells became smaller, and the leaves have been shown with broad inter cellular spaces (Singh, 1971).

Biocontrol using plant growth-promoting rhizobacteria (PGPR) agent represents a potentially attractive alternative disease management approach since PGPR are known for growth promotion and disease reduction in crops (Jetiyanon and Kloepper, 2002). A number of plant growth promoting rhizobacteria have been implicated in the biocontrol of viral diseases in many crop plants such as Tomato spotted wilt virus (Kandan et al., 2003), Sunflower necrosis virus (Srinivasan et al., 2005), Banana bunchy top virus (Kavino et al., 2003) and TMV in tomato (Kirankumar, 2007). These viruses have been controlled essentially through induced systemic resistance (ISR) by activating defense genes encoding chitinase, beta-1, 3 glucanase, peroxidase, phenylammonia lyase and other enzymes (Srinivasan et al., 2005; Kirankumar, 2007) and chemicals (M'piga et al., 1997). Several antagonistic microorganisms such as Pseudomonas, Bacillus, Streptomyces, Gliocladium and Trichoderma spp. have the potential to control a variety of crop diseases. In other studies, beneficial microorganisms were combined with a naturalcompound such as chitin or chitosan to improve their biocontrol efficacy (Sid-Ahmed et al., 2003). The aim of the present study was to compare the histochemical changes in leaves of tomato due to ToLCV, with or without PGPR amendments along with chitosan treatments; and to study the elicitation of Induced systemic resistance (ISR) molecules the defense responses of plants induced by them.

\section{MATERIALS AND METHODS}

\section{Collection and preparation of viral inoculums}

The culture of ToLCV was obtained from the virus infected tomato plants in the field, Agricultural College, UAS, Dharwad, India, and inoculated to healthy tomato plants using whiteflies (Bemisia tabaci) as the vector and the infected plants were maintained in the glasshouse throughout the period of study.

\section{Vector culture rearing}

Whiteflies were collected from cotton and tobacco plants in the fields with the help of an aspirator by turning the leaves slightly upwards. Whiteflies were released onto the ToLCV diseased tomato plants grown in insect proof rearing cages which make the insects viruliferous after sucking of whiteflies on diseased leaves and their population were maintained by introducing younger tomato plants into the rearing cages.

\section{Release of viruliferous insects}

The viruliferous insects were collected from the diseased plants with the help of an aspirator, and released onto the leaves of healthy PGPR treated tomato seedlings. Immediately, the seedlings were placed in an insect proof rearing cage and insects allowed to feed on them for a week to cause infection by the virus. Thirty days old seedlings were used for release of the viruliferous insects. Thus, it was ensured that all seedlings were infected with ToLCV.

\section{Field study}

A field experiment was conducted to assess the effect of the selected PGPR strain and chitosan on reduction of disease severity and growth promotion in tomato plants. It was carried out at main agricultural research station, UAS, Dharwad, India, during summer (Jan- May, 2012). Five-week-old seedlings of variety pusa ruby, raised in a glasshouse were transplanted in the main field with plot size $20 \mathrm{~m} \times 10 \mathrm{~m}$ and $75 \mathrm{~cm} \times 60 \mathrm{~cm}$ spacing.

\section{Rhizobacterial treatment}

The bacteria were cultured on nutrient broth (Peptone, $5 \mathrm{~g}$; Beef extract, $3 \mathrm{~g} ; \mathrm{NaCl}, 5 \mathrm{~g} ; \mathrm{pH} 6.8-7.2 / \mathrm{Lit}$ ) and incubated at $28^{\circ} \mathrm{C}$ for 48 $\mathrm{h}$ with shaking at $150 \mathrm{rpm}$. Bacteria were pelleted after centrifugation for $5 \mathrm{~min}$ at $10000 \times \mathrm{g}$, and the pellet was mixed with sterile $1 \%$ carboxy methyl cellulose (CMC) suspensions (Himedia, Mumbai, India). The seeds were surface sterilized with sodium hypochlorite solution, placed in CMC-cell suspensions, air dried inside a laminar flow chamber and the biocoated seeds were sown in the plastic pots (10" diameter) having $10 \mathrm{~kg}$ capacity of soil. For soil application, the lignite based culture (1:3) was applied to soil @ $5 \mathrm{~kg} / \mathrm{ha}$ before sowing seeds and mixed well. For foliar application, the lignite based culture was filtered through a muslin cloth and sprayed @ 1\% (w/v) at 10 and 20 days after sowing (DAS). Control plants in pots without application of rhizobacteria were also maintained. All treatments were replicated five times and arranged in a randomized complete block design (RCBD).

\section{Chitosan treatment}

Bacteria were grown in nutrient broth medium on a shaker (150 $\mathrm{rpm})$ at $28^{\circ} \mathrm{C}$ for two days and centrifuged at $10000 \times g$ for $5 \mathrm{~min}$. 
Chitosan was dissolved in $100 \mathrm{mM}$ acetate buffer $(\mathrm{pH} \mathrm{4.5)}$ and the $\mathrm{pH}$ adjusted to 6.5 using $1 \mathrm{~N} \mathrm{NaOH}$. The cell pellet was mixed with chitosan solution (5\%). Crab-shell chitosans (deacetylation of about $90 \%$ ) from Sigma-Aldrich were used in this work. The surface sterilized tomato seeds were soaked in chitosan-cell suspensions and kept on a shaker for $3 \mathrm{~h}$ at $28^{\circ} \mathrm{C}$ and $100 \mathrm{rpm}$. The seeds were shaken in chitosan solution until they became fully coated. The biocoated seeds were dried inside a laminar flow chamber. At 25 DAS, both upper and lower surfaces of the leaves were sprayed with the chitosan solution $(1 \mathrm{mg} / \mathrm{ml})$ prepared in $100 \mathrm{mM}$ acetate buffer ( $\mathrm{pH} 4.5)$ and the $\mathrm{pH}$ was adjusted to 6.5 with $1 \mathrm{~N} \mathrm{NaOH}$.

\section{Sample collection, Enzyme and phenol estimation}

Leaf samples were collected at 45 DAS and 75 DAS from both inoculated and uninoculated (control) tomato plants. They were frozen immediately in liquid nitrogen, ground to a powder and stored at $-80^{\circ} \mathrm{C}$ until determination of phenylammonia lyase, chitinase, polyphenol oxidase and peroxidase activities. The peroxidase activity was assayed spectrophotometrically following the method described by Mahadevan and Sridhar (1986). The phenylammonia lyase activity was determined using the method described by Ross and Sederoff (1992). The polyphenol oxidase activity in leaves was estimated at 45 and 75 DAS following the method of Mayer et al. (1965). The chitinase activity was estimated at 45 and 75 DAS, following the method described by Miller (1959). The total phenol content in leaves was estimated at 45 and 75 DAS by following Folin Cio-calteau method (Sadasivam and Manickam, 1991).

Preparation of samples for histochemical changes using various staining techniques

\section{Affixing, deparaffinising and hydrating the sections onto the} slides

PGPR treated plants with or without amendment of chitosan and diseased plants were taken for the histochemical analysis. Tomato leaves after 45 days after inoculation (DAI) were used for histopathological studies. Leaf bits $(1.0 \times 0.5 \mathrm{~cm})$ were processed following the paper boat technique (Jensen, 1962). The sections of $10 \mu \mathrm{m}$ size embedded samples were taken using Leica microtome. An adhesive was prepared using gelatin at $1.5 \mathrm{~g} / 100 \mathrm{ml}$ distilled water, and a little quantity of potassium dichromate added to prevent fungal growth. A few drops of gelatin were added on to the surface of clean microslide. Sections were carefully placed on adhesive and slides were warmed slightly over hot plate maintained at $50^{\circ} \mathrm{C}$ for $1-2$ min to facilitate flattening and stretching of section ribbons. The excess adhesive was drained off and the slides were dried for $24 \mathrm{~h}$ at room temperature. The sections were deparaffinised using xylene and were then treated with different grades of alcohol for gradual dehydration. Later, the sections were subjected to staining either directly or after hydration depending on the requirement.After each step, the slides were blot dried to remove excess chemical adhered to the slides.

Staining, dehydration and mounting the sections for various biochemical analyses

The sections were subjected to histological and histochemical staining for localization of different cellular chemical compounds namely insoluble polysaccharides, proteins and nucleic acids. To observe anatomical changes in diseased leaves, sections were passed through safranin and fast green stains. Sections were stained in $1 \%$ safranin ( $1 \mathrm{~g}$ of safranin in $100 \mathrm{ml}$ of $50 \%$ alcohol) for $2 \mathrm{~h}$ and then dehydrated in 50,70 and 90\% alcohol for $5 \mathrm{~min}$, stained with $0.5 \%$ fast green $(0.5 \mathrm{~g}$ of fast green in $100 \mathrm{ml}$ of $95 \%$ alcohol) for $5 \mathrm{~min}$ and again dehydrated with 95\% alcohol for 5 min,cleaned in xylene and mounted in DPX.The assessment of total insoluble polysaccharides was followed by Periodic acid Schiff's (PAS) method (Hatchkiss, 1948). The reagents were prepared as described by Longley (1952). For the assessment of total proteins, the method developed by O' Brien and Mc Cully (1981) was used. For the staining of nucleic acids, the method of Toludine Blue $O$ was used (Chayen et al., 1973) .The dye Toludine blue was used for the purpose of detecting the richness of RNA and DNA in cells. The slides were photographed using a Axiostar plus ("Carl Zeiss") Bright field microscope with Canon power shot G2 digital camera attachment.

\section{Statistical analysis}

The data obtained from field experiments were subjected to Randomized Complete Block Design analysis (Gomez and Gomez, 1984). The level of significance used in the ' $F$ ' test was $P=0.05$. The critical difference values were calculated whenever the $F$ test values were significant.

\section{RESULTS AND DISCUSSION}

\section{Structural staining for anatomical changes}

Histopathological studies were conducted to study the changes occurring due to ToLCV infection as well as to study to what extent these changes are reduced by inoculation with biocontrol agents. The histopathological studies revealed more anatomical destruction in leaves of diseased plants as compared to treated and healthy plants. There were more intercellular spaces. The palisade cells were markedly reduced in size, and lost their columnar compact nature (Figure 1). The reduction in size of leaf tissues and their destruction may be due to metabolic changes in tissues causing hypotrophy in palisade and spongy parenchyma cells. Similar observations were recorded in infected papaya leaves (Singh, 1971), Cucumber mosaic virus (CMV) affected chilli leaves (Mishra and Singh, 1973), CMV infected tobacco leaves (Ehara and Mishawa, 1975), TMV infected tomato (Alok et al., 1986) and in pigeonpea infected by sterlity mosaic virus (Singh and Rathi, 1996a).

\section{Effect on polysaccharides content in leaves}

The studies also revealed reduction in insoluble polysaccharides in palisade and spongy parenchyma cells of diseased plants as compared to healthy plants, which showed rich concentration of polysaccharides in the cells. The treatments receiving Pseudomonas sp. 206(4) +chitosan and Pseudomonas sp. B-15+Chitosan showed almost the same concentration of polysaccharides as seen in healthy cells whereas, Pseudomonas sp. 206(4) and Pseudomonas sp. B-15 showed a slight reduction in 


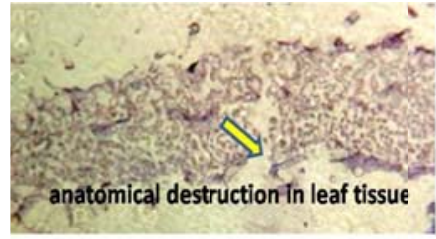

Disease control

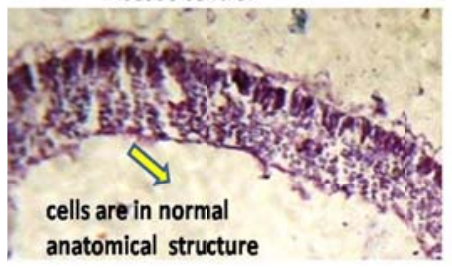

Pseudomonas sp. 206(4)

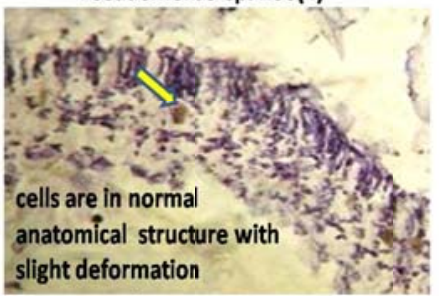

Pseudomonas sp. B-15

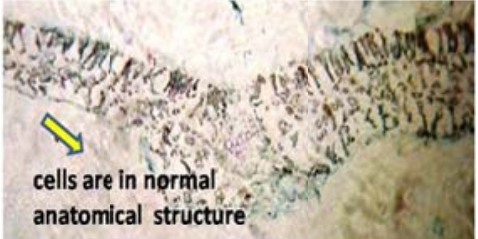

Healthy control

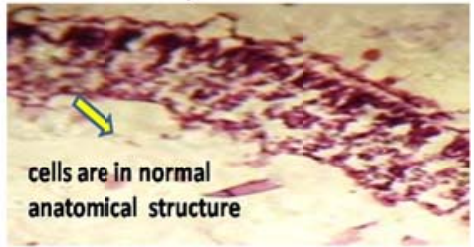

Pseudomonas sp. 206(4)+ Chitosan

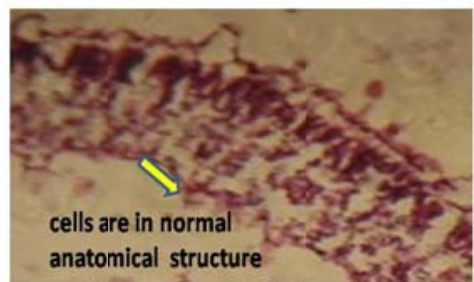

Pseudomonas sp. B-15 + Chitosan

Figure 1. Structural changes in tomato leaves after treatment with various selected rhizobacteria in combination with or without chitosan. The leaves were sampled $45 \mathrm{DAl}$ for dissection.

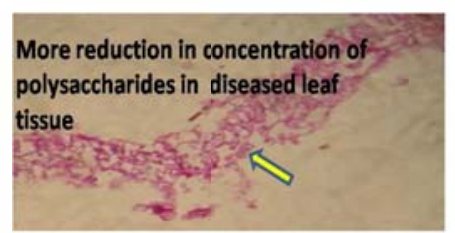

Disease control

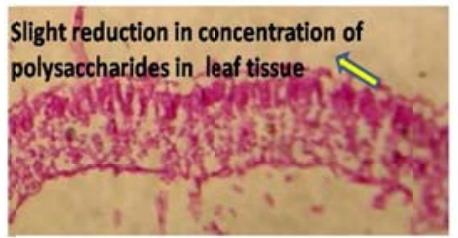

Pseudomonas sp. 206(4)

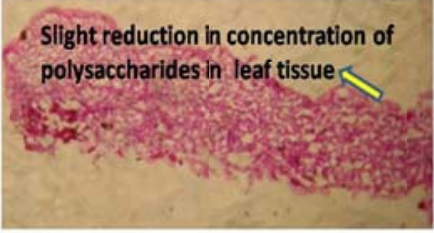

Pseudomonas sp. B-15

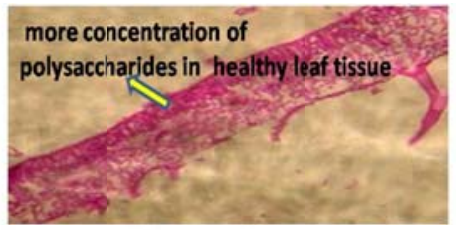

Healthy control

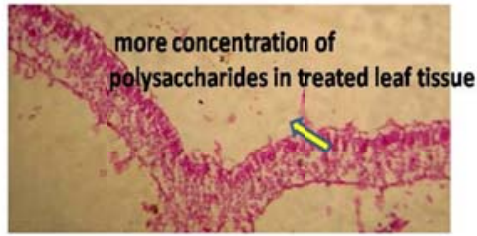

Pseudomonas sp. 206(4) + Chitosan

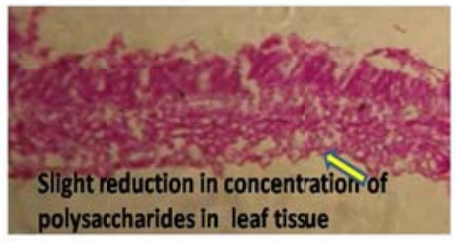

Pseudomonas sp. B-15 + Chitosan

Figure 2. Histochemical changes (polysaccharides) in tomato leaves after treatment with various selected rhizobacteria in combination with or without chitosan. The leaves were sampled 45 DAI for dissection.

concentration of polysac-charides in palisade and spongy parenchyma cells (Table 1 and Figure 2). The reduction in polysaccharides may be due to varied metabolism in infected tissues. Several workers have reported signifi- 
Table 1. Histochemical changes in healthy, treated and ToLCV infected leaves of tomato plants (At $45 \mathrm{DAI})$.

\begin{tabular}{|c|c|c|c|c|}
\hline \multirow{2}{*}{ Status } & \multirow{2}{*}{ Histochemical } & \multicolumn{3}{|c|}{ Different regions of leaf } \\
\hline & & Epidermis & Palisade parenchyma & Spongy parenchyma \\
\hline \multirow{3}{*}{ Healthy } & Polysaccharides & +++ & +++ & +++ \\
\hline & Proteins & ++++ & ++++ & +++ \\
\hline & Nucleic acids & ++ & ++ & ++ \\
\hline \multirow{3}{*}{ Diseased } & Polysaccharides & + & + & + \\
\hline & Proteins & + & + & + \\
\hline & Nucleic acids & ++++ & ++++ & ++++ \\
\hline \multirow{3}{*}{ Pseudomonas sp.206(4)+Chitosan treatment } & Polysaccharides & +++ & +++ & +++ \\
\hline & Proteins & +++ & +++ & ++ \\
\hline & Nucleic acids & ++ & ++ & ++ \\
\hline \multirow{3}{*}{ Pseudomonas sp.206(4) treatment } & Polysaccharides & ++ & ++ & ++ \\
\hline & Proteins & ++ & ++ & ++ \\
\hline & Nucleic acids & +++ & +++ & +++ \\
\hline \multirow{3}{*}{ Pseudomonas sp.B-15+Chitosan treatment } & Polysaccharides & +++ & +++ & +++ \\
\hline & Proteins & +++ & +++ & ++ \\
\hline & Nucleic acids & ++ & ++ & ++ \\
\hline \multirow{3}{*}{ Pseudomonas sp.B-15 treatment } & Polysaccharides & + & + & + \\
\hline & Proteins & ++ & ++ & ++ \\
\hline & Nucleic acids & +++ & +++ & +++ \\
\hline
\end{tabular}

++++, Very rich; +++ rich; ++ Medium; +, Low.

cant decrease in total sugars, reducing sugars and nonreducing sugars in diseased leaves (Khurana, 1970; Singh, 1973; Johri, 1975).

\section{Effect on nucleic acid content in leaves}

Nucleic acid content was found to be greater in palisade and spongy cells of diseased leaves when compared to healthy leaves. The manifestation of increase in nucleic acid content might be due to the combined effect of host and viral nucleic acid. Usually, concentration of virus in infected cells increases rapidly upon infection, thus, increasing their nucleic acid concentration in such cells. The treatments of Pseudomonas sp. 206(4)+ chitosan, and Pseudomonas sp. B-15 + chitosan showed almost similar nucleic acid quantity as seen in healthy cells whereas, Pseudomonas sp. 206(4) and Pseudomonas sp. B-15 showed a slight increase in nucleic acid content in palisade and spongy parenchyma cells (Table 1 and Figure 3 ). Our results are corroborative with the results obtained by Joshi and Dubey (1974) for the CMV infected chili-pepper leaves, infected nuclei of tobacco (Russo and Martell, 1975), nucleic acids and chloroplasts of tomato cells infected by ToLCV (Channarayappa et al., 1992). Similar effect was also reported by Singh and Rathi (1996b), where the presence of foreign ribonucleo protein in cytoplasm and nucleus of virus infected pigeonpea and increase in total nucleic acid in virus infected host tissues of papaya (Johri, 1975).

\section{Effect on protein content in leaves}

There was a significant higher reduction of protein content in palisade and spongy parenchyma cells from infected plants when compared to healthy plants; this might be due to the degradation of host protein or reduction in synthesis of protein subsequent to viral infection since virus uses host cell contents for replication. The combined treatment of the plants with Pseudomonas sp. 206(4)+chitosan, Pseudomonas sp. B$15+$ chitosan showed almost the same quantity of proteins as seen in healthy cells; while, the individual application of Pseudomonas sp. 206(4) and Pseudomonas sp. B-15 showed a reduction in protein content in palisade and spongy parenchyma cells (Table 1 and Figure 4). The reduction of protein content by $41 \%$ in diseased papaya 


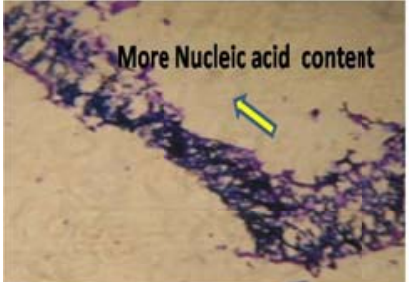

Disease control

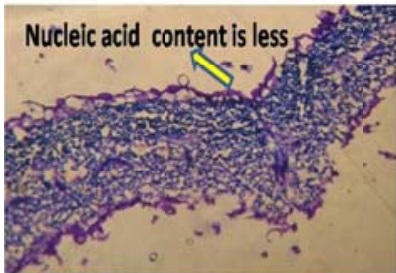

Pseudomonas sp. 206(4)

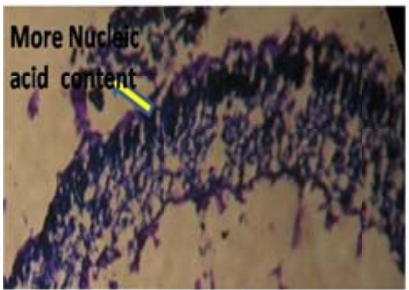

Pseudomonas sp. B-15

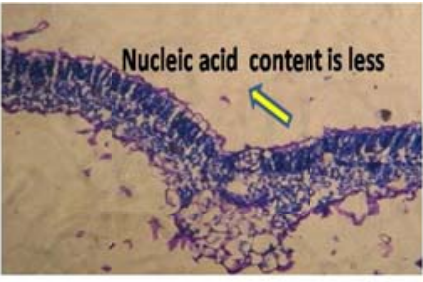

Healthy control

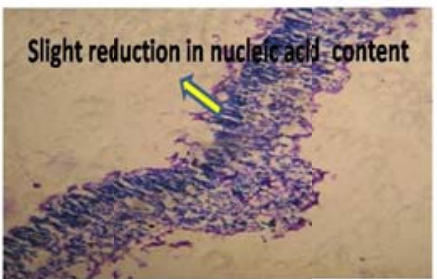

Pseudomonas sp. 206(4)+Chitosan

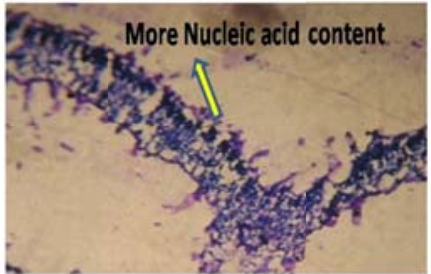

Pseudomonas sp. B-15 + Chitosan

Figure 3. Histochemical changes (nucleic acid) in tomato leaves after treatment with various selected rhizobacteria in combination with or without chitosan. The leaves were sampled 45 DAl for dissection.

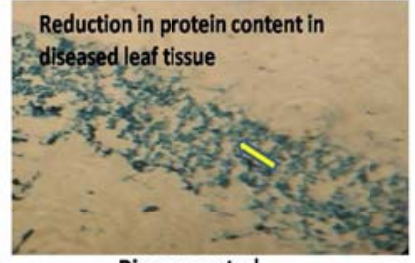

Disease control

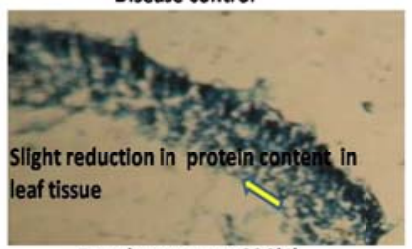

Pseudomonas sp. 206(4)

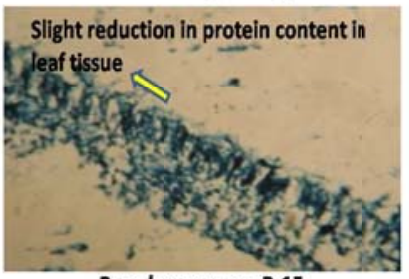

Pseudomonas sp. B-15

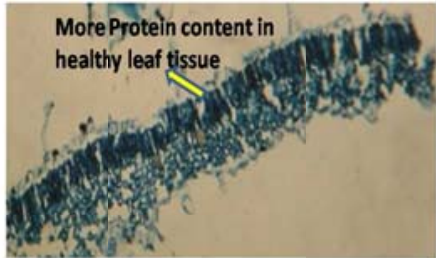

Healthy control

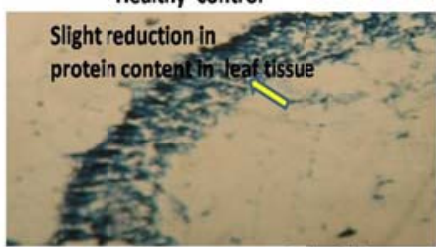

Pseudomonas sp. 206(4) + Chitosan

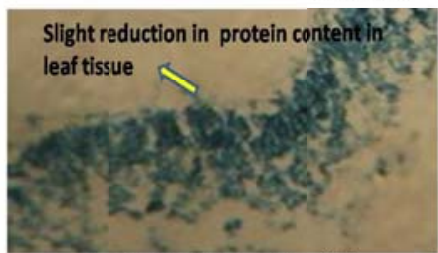

Pseudomonas sp. B-15 + Chitosan

Figure 4. Histopatholgical changes (proteins) in tomato leaves after treatment with various selected rhizobacteria in combination with or without chitosan. The leaves were sampled 45 DAl for dissection. 


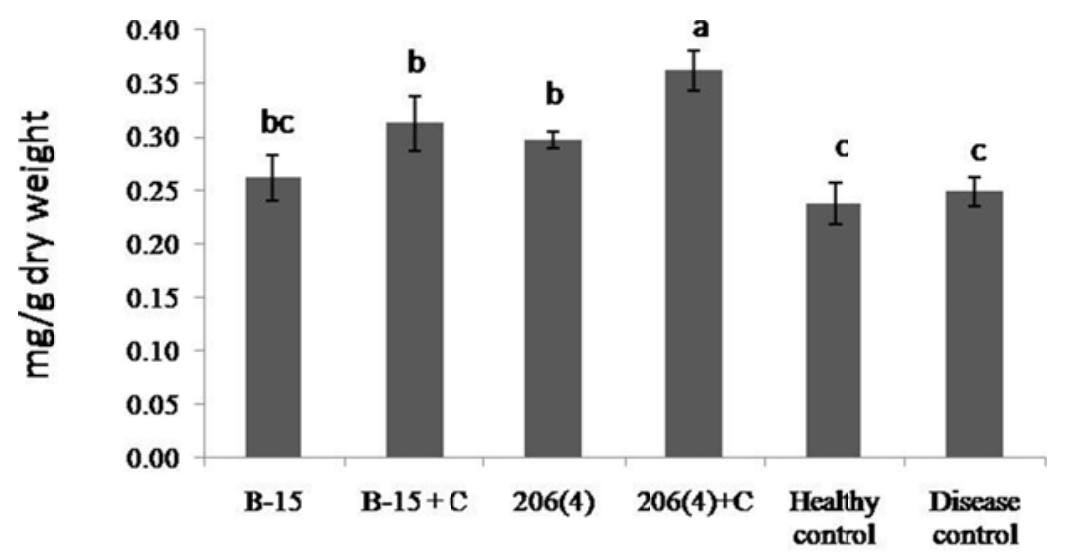

Treatments

Figure 5a. Effect of treatment with various selected rhizobacteria in combination with or without chitosan on phenol content in tomato leaves. Phenol content was estimated 45 days after sowing (DAS). Different letters on bars indicate statistically significant between treated and control according to LSD $(P=0.05)$. Each value represents the mean of three replications per treatment. Error bars indicate \pm standard error $(\mathrm{SE})$. Here, $\mathrm{C}$ represents chitosan.

fruits was earlier reported (Singh et al., 1977; Sun, 1985). The histochemical analysis from our study revealed that there was an increase of nucleic acid and decrease of insoluble polysaccharides, and also protein content due to ToLCV infection.

\section{Effect of rhizobacteria and chitosan on disease resistance against ToLCV through induced systemic resistance in tomato plants}

Bio-control agents, mainly bacterial inoculants are believed to induce systemic defense responses in the plants besides other antagonistic mechanisms. Induction of defense responses by plant-growth-promoting rhizobacteria (PGPR) is largely associated with the production of pathogenesis related (PR) proteins like b-1,3glucanase and the defense enzyme phenylalanine ammonia-lyase and oxidative enzymes like peroxidase and polyphenol oxidase (Compant et al., 2005). There was a greater level of phenolics in plants inoculated with Pseudomonas sp. and chitosan compared to unionculated plants. These results are in agreement with previous results, where there was increased phenolics content in cowpea due to $P$. fluorescens inoculation which, in turn, protected plants from spotted wilt virus (Kandan et al., 2003). An increased chitinase activity resulted in preventing the damage caused by viral pathogen and, thus, increased the disease control percentage in all the rhizobacteria treated plants. There was induction in biosynthesis of defense molecules in all the treated plants. Combined application of Pseudomonas sp. 206(4) and chitosan on tomato plants resulted in the highest synthesis of phenol content, PO, PPO, chitinase and PALase activity which accounts to $30.55,49.31$, $38.79,32.90$ and $34.78 \%$ respectively; higher than the diseased control. The role of PPO in disease resistance is to oxidize phenolic compounds to quinones, which are often more toxic to microorganisms than the original phenols and the enzyme itself is inhibitory to viruses by inactivating the RNA of the virus (Vidhyasekaran, 1988). Though all the treatments induced biosynthesis of phenolics, PAL, peroxidase, chitinase and polyphenol oxidase, the Pseudomonas sp. 206(4) + Chitosan treatment showed a greater defense activity compared to disease control (Figure 5). Cinammic acid, the product of PAL, is directly linked to cell lignification processes and the highest levels of PAL activity usually occur about one day after initial infection of pathogen (Podile and Laxmi, 1998). The PO and PPO activities are linked to lignifycation and generation of hydrogen peroxides at later stages of infection, which inhibit pathogens directly, or generation of other free radicals with antimicrobial activity, that restrict the development of pathogens (Silva et al., 2004).

Application of rhizobacteria in combination with or without chitosan reduced the ToLCV severity by $58-70 \%$. The treatment receiving Pseudomonas sp. 206(4)+ chitosan reduced the disease severity by $68 \%$ whereas the treatment receiving Pseudomonas sp. B-15+ chitosan exhibited $68.30 \%$ ToLCV severity control under field condition (Figure 5f). Thus, the observed induction of enzymes and the corresponding reduction in ToLCV infection in tomato supports the hypothesis that the 


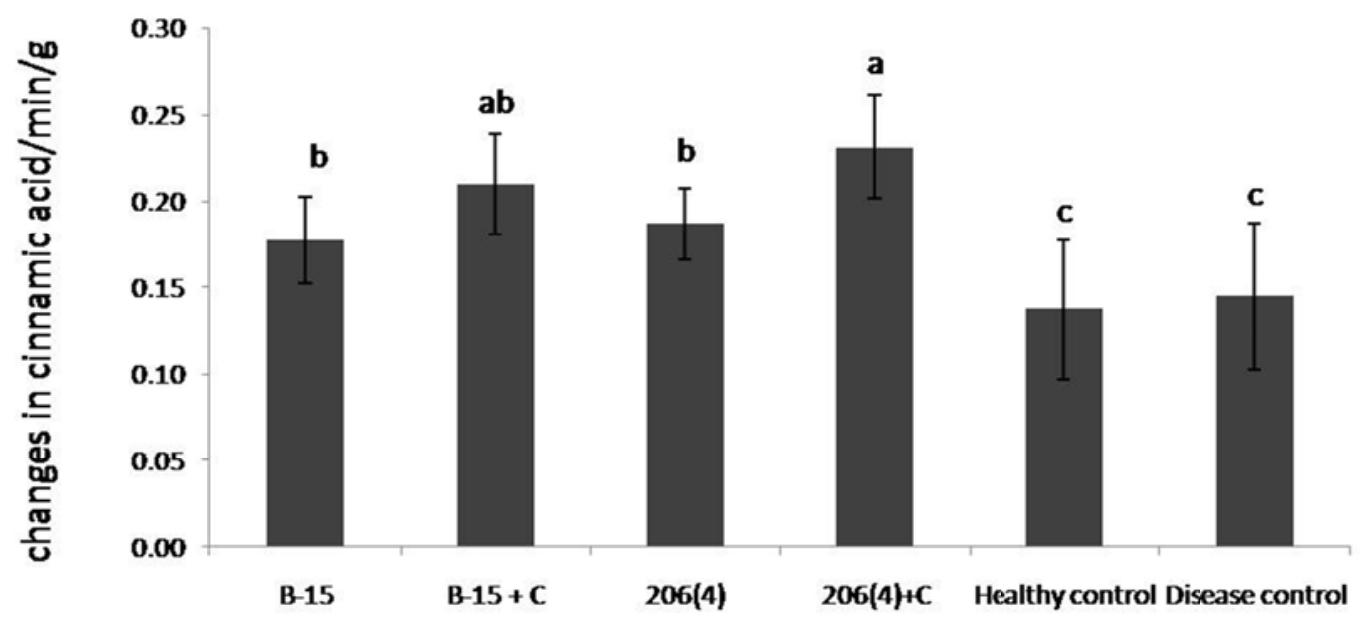

Treatments

Figure 5b. Effect of treatment with various selected rhizobacteria in combination with or without chitosan on phenylalaine ammonia lyase activity in tomato leaves. Phenylalaine ammonia lyase activity was estimated 45 days after sowing (DAS). Different letters on bars indicate statistically significant between treated and control according to LSD $(P=0.05)$. Each value represents the mean of three replications per treatment. Error bars indicate \pm standard error (SE). Here, C represents chitosan.

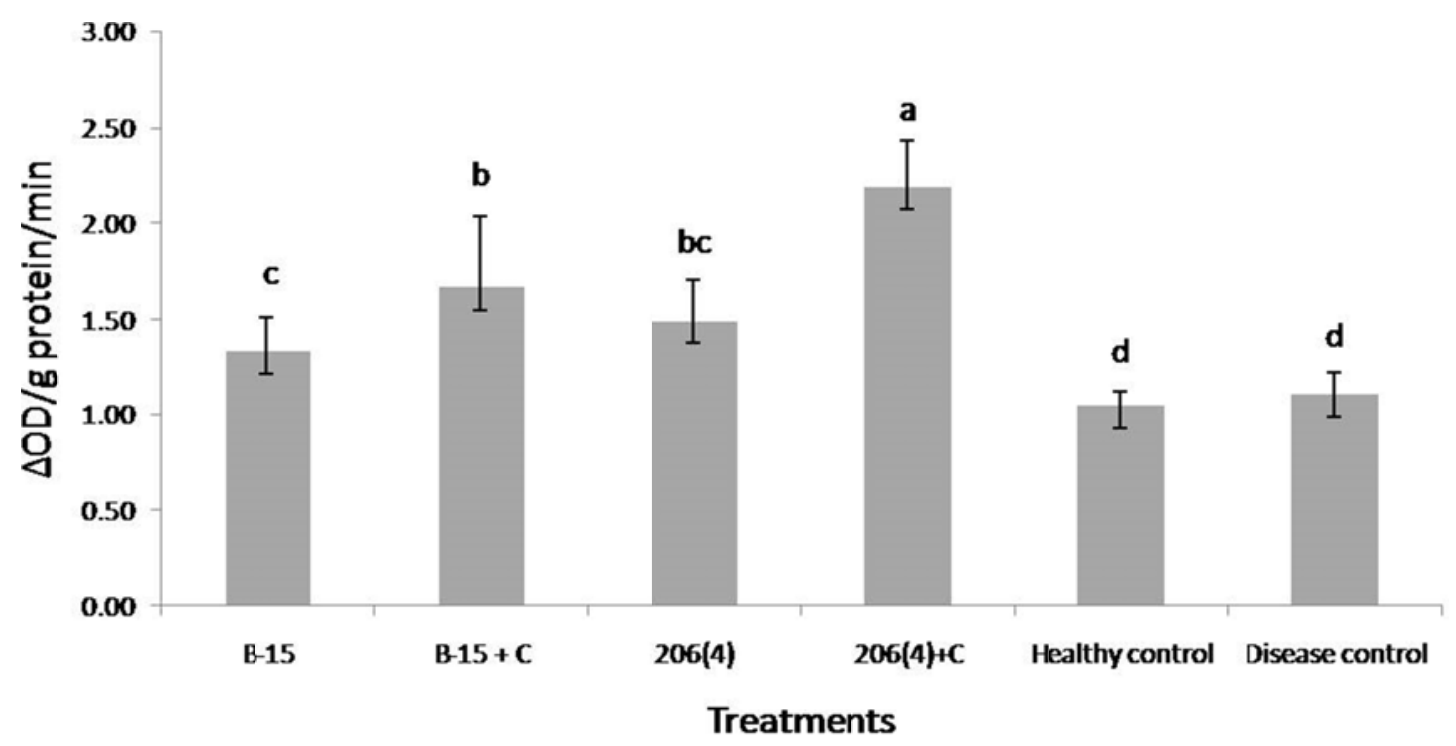

Figure 5c. Effect of treatment with various selected rhizobacteria in combination with or without chitosan on peroxidase activity in tomato leaves. Peroxidase activity was estimated 45 days after sowing (DAS). Different letters on bars indicate statistical significance between treated and control according to LSD $(P=0.05)$. Each value represents the mean of three replications per treatment. Error bars indicate \pm standard error (SE). Here, $\mathrm{C}$ represents chitosan.

resistance induced by isolates is systemic.

The increase in callose content as well as induction in ribonuclease and $\beta-1,3$ glucanase in potato plants as defense response against potato virus $X(P V X)$ were observed when plants were sprayed with chitosan solution $(1 \mathrm{mg} / \mathrm{ml})$. In other observation, there was enhanced activation of catalase, PAL, Peroxidase, PPO and chitinase levels in sunflower when seeds were treated with chitosan $(5 \%)$ for controlling downy mildew (Chirkov et al., 2001; Nandeeshkumar et al., 2008). Similar observations were reported with the potato virus $X$, tobacco mosaic and necrosis viruses, alfalfa mosaic 


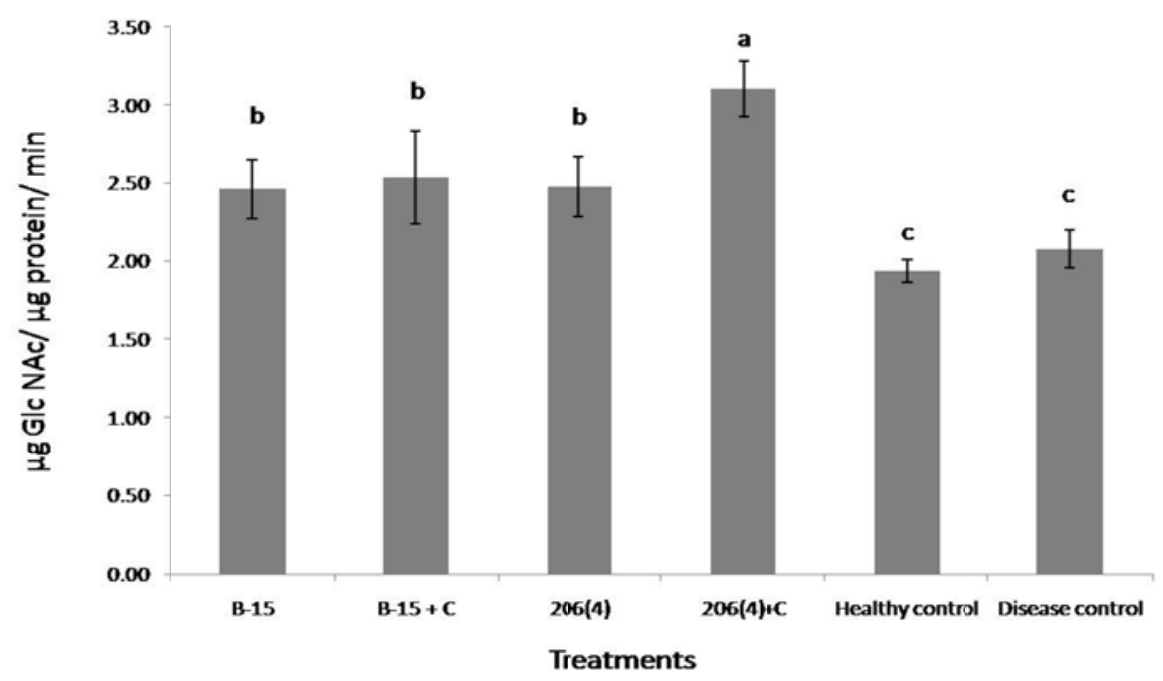

Figure 5d. Effect of treatment with various selected rhizobacteria in combination with or without chitosan on chitinase activity in tomato leaves. Chitinase activity was estimated 45 days after sowing (DAS). Different letters on bars indicate statistically significant between treated and control according to $\operatorname{LSD}(P=0.05)$. Each value represents the mean of three replications per treatment. Error bars indicate \pm standard error (SE). Here, $\mathrm{C}$ represents chitosan.

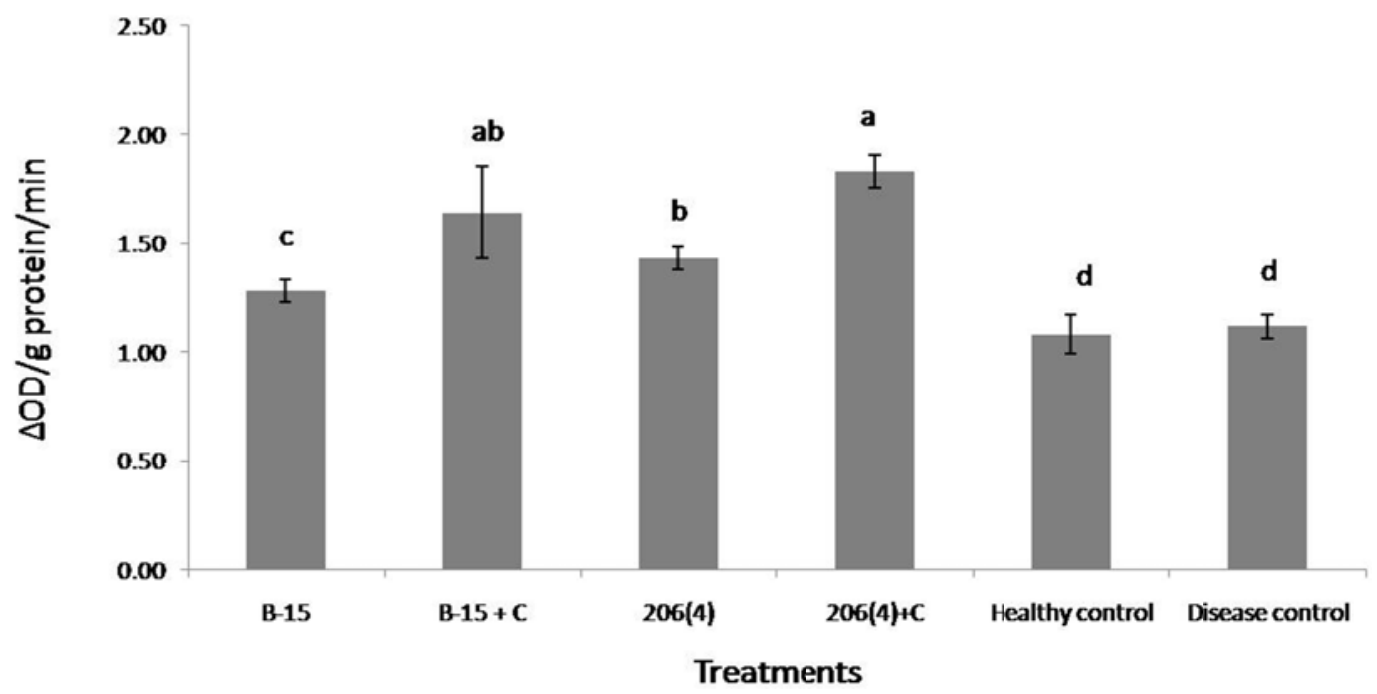

Figure 5e. Effect of treatment with various selected rhizobacteria in combination with or without chitosan on polyphenol oxidase activity in tomato leaves. Polyphenol oxidase activity was estimated 45 days after sowing (DAS). Different letters on bars indicate statistical significance between treated and control according to LSD $(P=0.05)$. Each value represents the mean of three replications per treatment. Error bars indicate \pm standard error (SE). Here, $C$ represents chitosan.

virus, cucumber mosaic virus (Chirkov, 2002).

\section{Conclusion}

In the present research, we showed that Pseudomonas sp. 206(4) combined with chitosan is a potential biocontrol agent with strong and reproducible biocontrol effects on controlling disease severity of ToLCV in tomato plants. Histochemical studies revealed reduction in insoluble polysaccharides and proteins and increase in nucleic acid content in palisade and spongy parenchyma cells of diseased plant as compared to treated and healthy plant. Histochemical studies also clearly indicated 


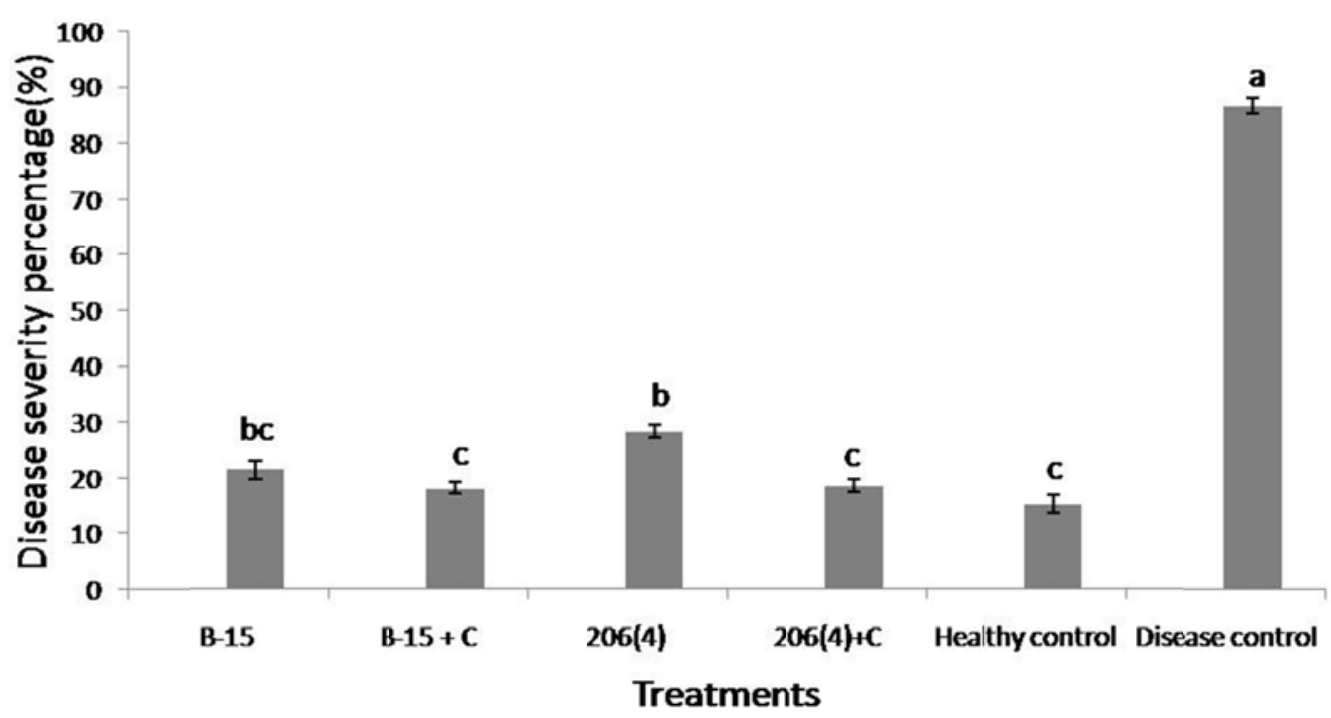

Figure 5f. Disease severity percentage exhibited by selected rhizobacteria in combination with or without chitosan after 75 days of pathogen(ToLCV) inoculation.Different letters on bars indicate statistical significance between treated and control according to LSD $(P=0.05)$. Each value represents the mean of three replications per treatment. Error bars indicate \pm standard error (SE). Here, $\mathrm{C}$ represents chitosan.

that rhizobacteria+chitosan biopreparation is more effective in controlling ToLCV as compared to rhizobacteria alone. Although the histopathological and histochemical studies revealed more destruction in the diseased plants, these changes could be reduced to the level of the healthy plants due to combined treatment of chitosan and Pseudomonas sp.

\section{Conflict of Interests}

The author(s) have not declared any conflict of interest.

\section{ACKNOWLEDGMENTS}

The authors thank the University of Agriculture Sciences, Dharwad, India for providing the University Merit Scholarship during the course of the study. Sincere thanks goes to Dr. M. Jayaraj, Professor, Department of Botany, Karnataka University, Dharwad and his Ph.D student Pramod Pattar for their valuable help during the histopathology work.

\section{REFERENCES}

Abdelbasset EH, Adam LR, Hadrami IE, Daayf F (2010).Chitosan in Plant Prot. Mar. Drugs 8: 968-987.

Alok K, Bansal RD, Kaul VK, Cheema SS (1986). Histopathological changes induced in tomato plants by single and combined infection of tobacco mosaic virus and Alternaria solani. Indian Phytopathol. 39: 346-350.

Channarayappa MV, Schwegler BD, Shivashankar G (1992).
Ultrastructural changes in tomato infected with tomato leaf curl virus a whitefly-trasmitted geminivirus. Can. J. Bot. 70:1747-1753.

Chayen J, Bitensky L, Brucher RG (1973). Practical histochemistry. Wiley Newyork.

Chirkov SN (2002). The antiviral activity of chitosan. Appl. Biochem. Microbiol. 3:81-89.

Chirkov SN, li'ina AV, Surgucheva NA, Letunova EV, Varitsev YA, Tatarinova NY, Varlamov VP (2001). Effect of chitosan on systemic viral infection and some defense responses in potato plants. Russ. J. Plant Physiol. 48:774-779.

Compant S, Duffy B, Nowak J, Cle'ment C, Barka EA (2005). Use ofplant growth promoting bacteria for biocontrol of plant diseases:principles, mechanisms of action, and future prospects. Appl. Environ. Microbiol. 71:4951-4959.

Doares SH, Syrovets T, Weiler EW, Yan CA (1995).Oligogalacturonides and chitosan activate plant defensive genes through the octadecanoid pathway. Proc. Natl. Acad. Sci. USA 92: 4095-4098.

Ehara Y, Misawa T (1975). Occurrence of abnormal chloroplasts in tobacco leaves infected systemically with ordinary strain of cucumber mosaic virus. Phytopathology 84: 233-252.

Gomez KA, Gomez AA (1984). Statistical Procedures for Agricultural Research.An International Rice Research Institute Book Wiley-Inter Science Publication New YorkUAS. p. 680.

Harrison BD, Muniyappa V, Swanson MM, Roberts IM, Robinson DJ (1991). Recognition and differentiation of seven whitefly transmitted Geminiviruses from India and their relationships to African cassava mosaic and Thailandmungbean yellow mosaic viruses. Ann. Appl. Biol.118:299-308.

Hatchkiss RD (1948). Micro-chemical reaction in the staining of polysaccharide structures in fixed tissue preparations. Arch. Biochem. 16:131-141.

Jensen WA (1962). In: Botanical Histochemistry Wit Freeman Co. San Fransisco USA. pp. 198-199.

Jetiyanon K, Kloepper JW (2002). Mixtures of plant growthpromoting rhizobacteria for induction of systemic resistance against multiple plant diseases. Biol. Control 24:285-291.

Johri JK (1975). Post infection changes in nitrogen metabolosm in virus infected Carica papaya L. Indian J. Exp. Biol.13: 220-221.

Joshi RD, Dubey LN (1974). Some studies on metabolism of virus infected chilli (Capsicum annuum L.) I. Effect of cucumber mosaic 
virus on ribonucleic acid content. Proc. Natl. Sci. India 44: 246-249. Kandan A, Radjacommare R, Ramiah M, Ramanathan A, Samiyappan $R$ (2003). PGPR induced systemic resistance in cowpea against tomato spotted wilt virus by activating defense against tomato spotted wilt virus by activating defense related enzymes and compound. In: Proceedings of the Sixth International Workshop on Plant Growth Promoting Rhizobacteria Ed. Y.R. Sarma IISR Publishers Calicut. pp. 480-486.

Kavino M, Harish S, Kumar N, Soorianathasundaram K, Ramanathan A, Samiyappan R (2003). PGPR induced systemic resistance against banana bunchy top virus in banana. In: Proceedings of the Sixth International Workshop on Plant Growth Promoting Rhizobacteria Ed. Y.R. Sarma IISR Publishers Calicut. pp. 486-492.

Khurana SMP (1970). Effect of virus diseases on the latex and sugar contents of papaya fruits. J. Hortic. Sci. 45: 295-297.

Kirankumar R (2007). Evaluation of Plant growth promoting rhizobacterial stains against TMV on tomato. M. Sc Thesis University of Agricultural Sciences Dept. of Agricultural Microbiology. Dharwad (India).

Longley JB (1952). Effectiveness of Schiff variance in the Periodic Schiff and Fenglen nucleus techniques. Stain Techn. 27:161-169.

M'Piga, Belanger RR, Paulitz TC, Benhamli N (1997). Increased resistance to tomato plants treated with endophytic bacterium Pseudomonasfluorescens. Physiol. Mol. Plant Pathol. 50: 301-320.

Mahadevan A, Sridhar R (1986). Methods in Physiological Plant Pathology.Sivakami Publishers Madras. p. 103.

Mayer AM, Harel E, Shaul RB (1965). Assay of Catechol oxidase: a critical comparison of methods. Phytochemistry 5:783.

Miller GL (1959). Use of dinitrosalicyclic acid reagent for determination of reducing sugar. Anal. Chem. 31: 426-428.

Mishra AK, Singh TKS (1973).Phytopathological anatomy of virus infected chilli plants. Indian Phytopathol. 26: 111-114.

Muniyappa V, Veeresh GK (1984). Plant virus diseases transmitted by whiteflies in Karnataka. Proc. Indian Acad. Sci. 93: 397-406.

Nandeeshkumar P, Sudisha J, Kini K, Ramachandra HS, Prakash SR, Niranjana M, Shetty HS (2008). Chitosan induced resistance to downy mildew in sunflower caused by Plasmoparahalstedii. Physiol. Mol. Plant Pathol. $72: 188-194$.

O' Brien TP, Mccully ME (1981). The study of plant structure : principles and selected methods. Termarcarphi Ltd. Melourne.

Podile AR, Laxmi VDV (1998). Seed bacterization with Bacillus subtilis increases phenyl alanine ammonia lyase and reduces the incidence of fusarial wilt of pigeon pea. J. Phytopathol. 146: 255-259.

Ross WW, Sederoff RR (1992). Phenylalanine ammonia lyase activity from lobally pine: Purification of the enzyme and isolation of complementary DNA clones. Plant Physiol. 98: 380-386.

Russo M, Martell GP (1975). Some cytochemical reaction of nuclei infected with egg plant mottled dwarf virus. Phytopathology 83: 97102.

Sadasivam S, Manickam A (1991). Biochemical Methods for Agriculture Science Wiley Eastern Limited New Delhi. pp. 106-108.

Saikia AK, Muniyappa V (1989). Epidemiology and control of tomato leaf curl virus in Southern India. Trop. Agric. 66:350-54.

Sid-Ahmed A, Ezziyyani M, Pérez- Sánchez C, Candela ME (2003). Effect of chitin on biological control activity of Bacillus spp. and Trichodermaharzianum against root rot disease in pepper (Capsicum annuum) plants. Eur. J. Plant Pathol. 109 :633-637.

Silva HS, Aromeiro RS, Macagnan D, Halfeld-Vierira BA, Pereira MCB, Mounteer A (2004) Rhizobacterial induction of systemic resistance in tomato plants: non-specific protection and increase in enzyme activities. Biol. Control 29:288-295.

Singh AB (1971). Changes in the anatomy of papaya leaf infected with papaya leaf reduction virus. Philippine Agric. 54:474-477.

Singh $A B$ (1973). The effect of infection with papaya leaf reduction virus on the total nitrogen and carbohydrate content of papaya leaves. Phyton. Ann. Rev. Bot. 15:37-43.

Singh AB, Nimbalkar MR, Pandey PK (1977). Destruction of chlorophyll $A$ and $B$ in papaya leaves infected with Papaya ringspot virus. Sci. Cult. 43:89.
Singh AK, Rathi YPS (1996a).Histopathological studies in sterility mosaic affected pigeonpea using fluorescent and light microscopy. Indian J. Virol. 12:151-153.

Singh AK, Rathi YPS (1996b). Nuclear inclusion produced in phloem cells pigeonpea diseased mid vein infected with pigeon pea sterility mosaic virus (PSMV). Indian J. Virol. 12:147-149.

Srinivasan K, Surendiran G, Maathivanan N (2005). Pathological and molecular biological investigations on sunflower necrosis virus (SNV) and ISR mediated biological control of SNV by PGPR strains. Asian Conference on Emerging Trends in Plant- Microbe Interaction 8-10 December Chennai India. pp. 282-285.

Sun GC (1985). Effect of infection of ringspot mosaic on the chlorophyll contents and activity of photosynthetic carboxylase in papaya leaves. Acta Phytopathol. Sin. 15:15-18.

Thind SK, Monga PK, Nirmaljit K, Cheema SS (1996). Analysis of some biochemical and micro nutrient constituents of yellow mosaic virus infected moong. Indian J. Virol. 12 (2):157-159.

Vidhyasekaran $P$ (1988). Physiology of disease resistance in plants. Vol I. Boca Raton FL: CRC Press. 